\title{
Evaluation of a New Assay Kit for Intrinsic Factor Blocking Antibody (Type I) as an Aid in the Diagnosis of Pernicious Anemia
}

\author{
Wen-Liang CHEN, Reiji MorishitA, Tadashi EgUCHI, \\ Toshihide KAWAI, and Haruto UCHINO ${ }^{1}$ \\ The First Division, Department of Internal Medicine, \\ Faculty of Medicine, Kyoto University, \\ Sakyo-ku, Kyoto 606, Japan
}

(Received April 10, 1985)

\begin{abstract}
Summary Sera from 39 patients with pernicious anemia and 251 patients with various other diseases and 42 healthy normal subjects were tested for intrinsic factor blocking antibody by a Corning commercial kit. Twenty-five $(64 \%)$ out of 39 pernicious anemia patients showed a positive reaction to the intrinsic factor blocking antibody. The positive incidence of intrinsic factor blocking antibody by this method agreed well with the results obtained in this laboratory over the past 10 years using the charcoal method. No sera from normal subjects tested were positive for the intrinsic factor blocking antibody. All 226 sera with vitamin B12 levels less than $3,500 \mathrm{pg} / \mathrm{ml}$ which came from patients without pernicious anemia, were negative for the intrinsic factor blocking antibody. In 15 sera with B12 levels greater than $3,500 \mathrm{pg} / \mathrm{ml}$ from patients who received recent B12 medications, 11 sera showed false positive results. On the other hand, no false positive results were obtained by this method in 10 sera with endogenous serum B12 levels greater than $3,500 \mathrm{pg} / \mathrm{ml}$ collected from patients with chronic myelogenous leukemia. It is reasonable to presume that this assay is clinically useful for detection of intrinsic factor blocking antibody in the diagnosis of pernicious anemia, if false positive results due to $\mathrm{B} 12$ medication are excluded.

Key Words intrinsic facter antibody, pernicious anemia, vitamin B12, radioassay
\end{abstract}

Two types of intrinsic factor (IF) antibodies have been demonstrated in patients with pernicious anemia (PA) $(1,2)$. The IF blocking antibody (Type I) prevents attachment of vitamin B12 (B12) to IF, while the IF binding antibody (Type II) combines with either IF alone or with IF-B12 to form a soluble complex. Type I antibody has been found in $51-76 \%$ of sera from PA patients $(3-5)$. and is

${ }^{1}$ 陳 文亮, 森下玲児, 江口 忠, 河合敏秀, 内野治人 
believed to have a sensitive specificity for the diagnosis of PA.

A commercial kit from Corning Medical and Scientific, which uses a highly purified porcine IF linked to glass particles for detecting a Type I antibody, has been evaluated for its usefulness in the diagnosis of PA. As false positive results were sometimes obtained in sera with highly elevated B12 levels, we tried to clarify the mechanisms.

\section{MATERIALS AND METHODS}

1. Serum samples. Serum samples from 39 PA patients (male 17, female 22, age $14-85 \mathrm{y}$ ) and 251 patients with other various diseases (male 119, female 132, age 6-81 y) were collected in fasting states and stored at $-20^{\circ} \mathrm{C}$. The diagnosis of PA was determined by clinical manifestations and laboratory data. Serum samples obtained from 42 healthy subjects (male 22, female 20, age 35-65y) were used as normal controls.

2. Detection of IF blocking antibody (Type I) by Corning IMMO phase assay. The kits were offered by Corning Medical and Scientific (Medfield, U.S.A.) and the assay protocol is shown in Table 1. The counts per minute (CPM) ratios of negative antibody calibrators to each sample were calculated.

3. Detection of IF blocking antibody (Type I) by the charcoal method $(6,7)$. Aliquots of $2 \mathrm{ml}$ of diluted normal human gastric juice ( $3.0 \mathrm{ng}$ of B12 binding capacity) in physiological saline were mixed well with $0.1 \mathrm{ml}$ of serum samples, and incubated at room temperature, for $10 \mathrm{~min}$. Then $0.1 \mathrm{ml}$ of ${ }^{57} \mathrm{Co}-\mathrm{B} 12$ $(10 \mathrm{nCi} / 5 \mathrm{ng})$ was added to each aliquot and mixed for $10 \mathrm{sec}$. Free ${ }^{57} \mathrm{Co}-\mathrm{B} 12$ was removed by centrifugation, after addition of $2.0 \mathrm{ml}$ of $2.5 \%$ bovine serum albumin-

Table 1. Protocol for Corning IF blocking antibody assay.

$0.1 \mathrm{ml}$ of negative, positive calibrators (quadruplicate) positive control, serum samples (duplicate)

Add $0.5 \mathrm{ml}$ of hog IF bound to glass particles which are suspended in phosphate beffered saline mix well for 3-4 sec incubate at room temp. for $2 \mathrm{~h}$

Add $2.0 \mathrm{ml}$ of deionized water without mixing centrifuge decant

Add $1.0 \mathrm{ml}$ of ${ }^{57} \mathrm{Co}-\mathrm{B}_{12}$ tracer solution mix well for 3-4 sec incubate at room temp. for $1 \mathrm{~h}$

Add $2.0 \mathrm{ml}$ of deionized water without mixing centrifuge decant

Count all tubes in a gamma counter for ${ }^{57} \mathrm{Co}$ radioactivity 
coated charcoal. The supernates were counted for ${ }^{57} \mathrm{Co}-\mathrm{B} 12$ radioactivity and the antibody titers of serum were recorded in terms of the quantity of ng B12 which was prevented from binding to IF. Diluted serum samples were used when the titers of IF antibody were high.

4. Detection of IF binding antibody (Type II) (8). Aliquots of $0.02 \mathrm{ml}, 0.05 \mathrm{ml}$ and $0.10 \mathrm{ml}$ of serum samples were mixed well with ${ }^{57} \mathrm{Co}-\mathrm{B} 12$-normal human gastric juice ( $5 \mathrm{ng}$ of B12 binding capacity). ${ }^{57} \mathrm{Co}-\mathrm{B} 12$-complex bound to Type II antibody was precipitated by addition of $1.0 \mathrm{ml}$ of saturated ammonium sulfate solution and spinning down. The precipitates were washed twice with $2.0 \mathrm{ml}$ of $33 \%$ ammonium sulfate solution and counted for ${ }^{57} \mathrm{Co}-\mathrm{B} 12$ radioactivity.

5. Serum B12 radioassay. Serum B12 level was determined by Phadebas B12 RIA kit (Pharmacia, Sweden)(9).

\section{RESULTS}

1. Accuracy of Corning IF blocking antibody assay

As shown in Table 2, the coefficients of variation both for the intra- and interassays were small, and a good reproducibility was obtained.

2. IF blocking antibody assay in PA patients (Table 3)

In 39 PA cases, $25(64 \%)$ were positive, 2 indeterminate, and $12(31 \%)$ negative for the IF blocking antibody in the Corning assay. In the test of the same PA sera by

Table 2. Precision of Corning IF blocking antibody assay.

\begin{tabular}{clcc}
\hline Precision & \multicolumn{1}{c}{ Sample } & $\begin{array}{c}\text { CPM ratio } \\
\mathrm{M} \pm \mathrm{SD}\end{array}$ & $\begin{array}{c}\text { Coefficient of } \\
\text { variation }(\%)\end{array}$ \\
\hline $\begin{array}{clc}\text { Intra-assay } \\
(n=5)\end{array}$ & $\begin{array}{l}\text { Negative Ab calibrator } \\
\text { Positive Ab calibrator }\end{array}$ & $\begin{array}{c}0.975 \pm 0.022 \\
1.266 \pm 0.047\end{array}$ & 2.3 \\
& Positive control & $1.883 \pm 0.097$ & 3.7 \\
\hline Inter-assay & Negative Ab calibrator & $1.002 \pm 0.031$ & 3.2 \\
$(n=3)$ & Positive Ab calibrator & $1.228 \pm 0.027$ & 2.1 \\
& Positive control & $1.728 \pm 0.048$ & 2.8 \\
\hline Intra-assay & Negative Ab calibrator & $0.986 \pm 0.041$ & 4.1 \\
by 3 & Positive Ab calibrator & $1.291 \pm 0.019$ & 1.5 \\
opperators & Positive control & $1.914 \pm 0.082$ & 4.3 \\
\hline $\begin{array}{c}\text { Inter-assay } \\
\text { with 4 kits }\end{array}$ & Negative Ab calibrator & $0.989 \pm 0.033$ & 3.3 \\
of different & Positive Ab calibrator & $1.314 \pm 0.083$ & 6.3 \\
lot's No. & Positive control & $1.859 \pm 0.195$ & 10.5 \\
\hline
\end{tabular}

${ }^{\mathrm{a}} \mathrm{CPM}$ ratio $=\mathrm{CPM}$ of negative $\mathrm{Ab}$ calibrator $/ \mathrm{CPM}$ of sample.

Vol. 31 , No. 5, 1985 
Table 3. Comparison of results obtained using charcoal procedure and Corning assay for 39 cases of pernicious anemia.

\begin{tabular}{ccccc}
\hline \multirow{2}{*}{ Charcoal } & $\begin{array}{c}\text { Antibody } \\
\text { positive }\end{array}$ & 25 & 1 & 4 \\
\cline { 2 - 5 } & Negative & 0 & 1 & 8 \\
\hline & Antibody & $\begin{array}{l}\text { Indeterminate } \\
\text { positive }\end{array}$ & $\begin{array}{l}\text { Antibody } \\
\text { negative } \\
\text { Corning }\end{array}$
\end{tabular}

the charcoal procedure, 30 cases $(77 \%)$ were positive and $9(23 \%)$ negative. The positive rate was higher in the charcoal procedure $(p<0.001)$. Four cases having low activities of serum IF blocking antibody $(2.8,5.3,9.2$ and $11.4 \mathrm{ng} / \mathrm{ml})$, checked by the charcoal procedure, had negative results in the Corning assay. In 26 cases with serum IF blocking antibody activities greater than $15.8 \mathrm{ng} / \mathrm{ml}$ by the charcoal procedure, one was in the indeterminate range and 25 cases showed positive results according to the Corning assay. One case with no IF blocking antibody activity checked by the charcoal procedure was in the indeterminate range according to the Corning assay. Eight cases showed negative results, checked by both methods. The results of the Corning assay agreed well with those of the charcoal procedure in PA patients.

3. IF blocking antibody assay in normal controls and patients without PA

1) Normal controls. In the 42 normal cases, all were negative in the Corning IF blocking antibody assay.

2) Patients with various diseases (serum B12 levels less than $3,500 \mathrm{pg} / \mathrm{ml}$ ). As shown in Fig. 1, all 226 sera from patients without PA, and having B12 levels less than $3,500 \mathrm{pg} / \mathrm{ml}$ were negative in the Corning IF blocking antibody assay.

4. Effects of serum B12 levels on results of Corning IF blocking antibody assay (Fig. 2)

1) Effects of endogenous high serum B12 levels. The serum B12 levels were higher than $3,500 \mathrm{pg} / \mathrm{ml}$ in 10 patients with chronic myelogenous leukemia without B12 medication. Sera from these 10 patients were all negative according to IF blocking antibody assay.

2) Effects of high serum B12 levels due to B12 medications. Thirteen patients received B12 injections in the recent days and 12 of them had serum B12 levels higher than $3,500 \mathrm{pg} / \mathrm{ml}$. Sera from eleven of the 12 patients showed false positive results in the IF blocking antibody assay. In these cases, 8 patients had received B12 injection within $24 \mathrm{~h}, 2$ patients had received B 12 medications 2 days previously, and one had received B12 injections 4 days previously. On the other hand, 3 of 8 patients who received B12 medication orally had serum B12 levels higher than 


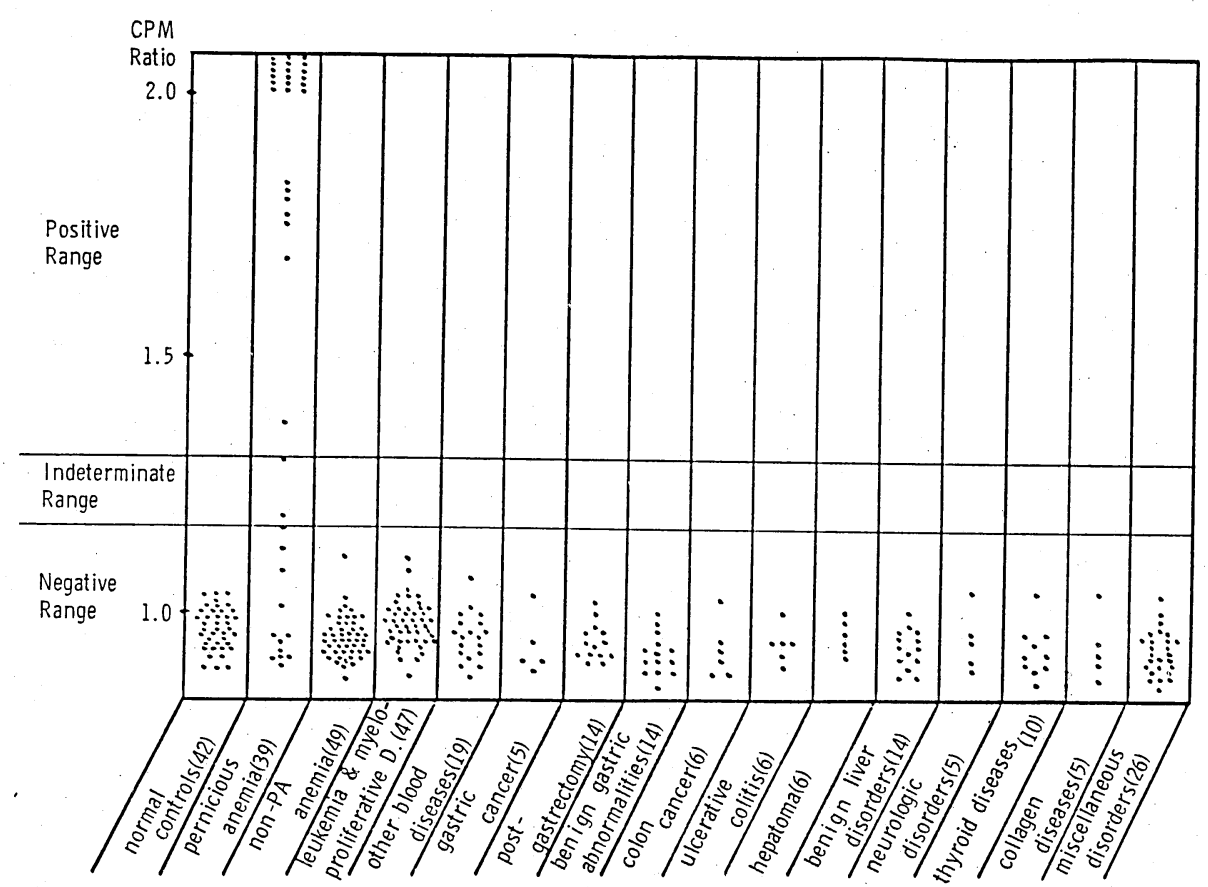

Fig. 1. Results of Corning IF blocking antibody assay in sera with B12 levels less than $3,500 \mathrm{pg} / \mathrm{ml}$.

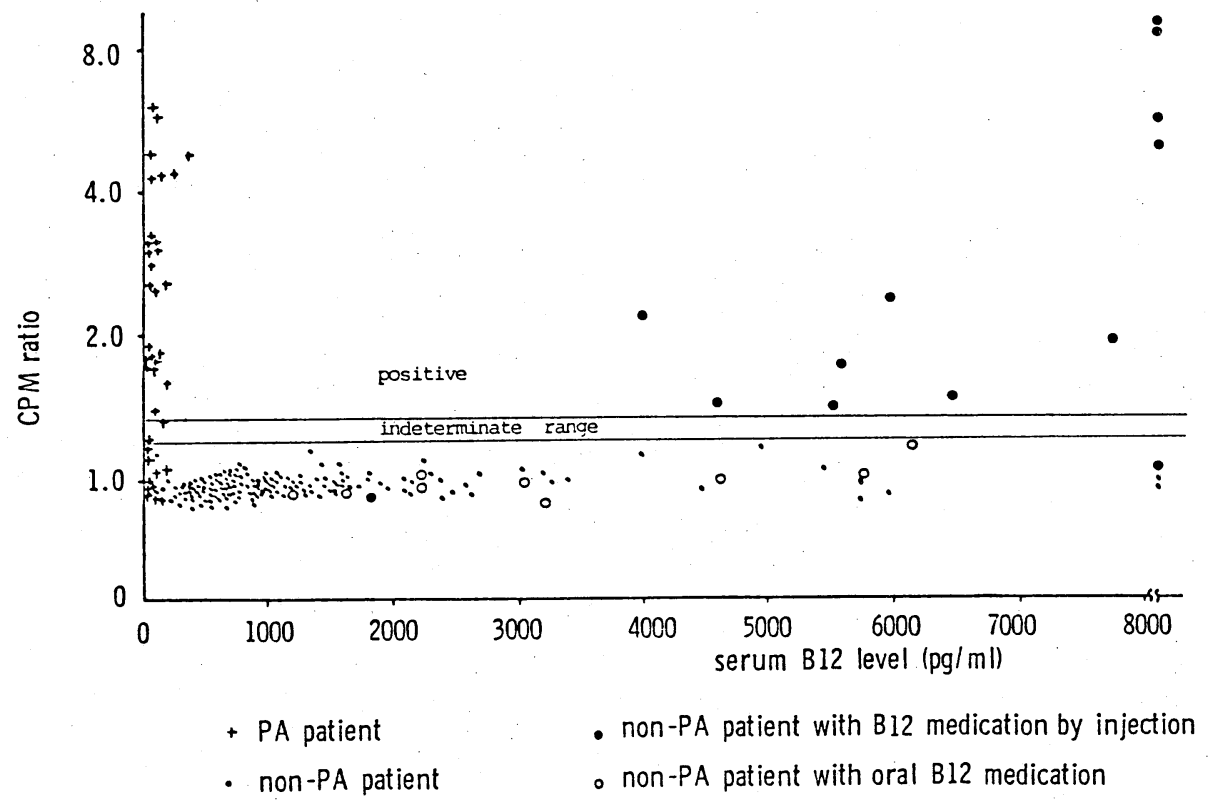

Fig. 2. Effect of serum B12 levels on the results of Corning IF blocking antibody assay.

Vol. 31 , No. 5, 1985 
$3,500 \mathrm{pg} / \mathrm{ml}$, but none showed false positive results in the IF blocking antibody assay.

5. Comparison of IF blocking antibody (Type I) and IF blocking antibody (Type II) in $P A$ patients

Seventeen (43\%) out of 39 PA cases had an IF binding antibody. All of these 17 cases tested were positive for the IF blocking antibody in the Corning IF blocking assay.

\section{DISCUSSION}

The Schilling test is used first for the diagnosis of PA. However, the test is not ideal, because the results may be affected by the patient's renal function and incomplete urine collection.

IF blocking antibody has been demonstrated in PA patients for more than 20 years (1) and has been confirmed to be useful in the diagnosis of PA. However, the assay for detecting this antibody is only available in large reference laboratories or private research laboratories. The Corning IF blocking antibody assay is the first commercial RIA kit put into market for the detection of this antibody. It uses highly purified IF linked to glass particles, and is easy to handle. In this study, $64 \%$ of 39 cases of PA were positive for IF blocking antibody. This is in good agreement with the results by a charcoal procedure accumulated over the past 10 years in this laboratory. Additionally, all cases with positive IF Type II antibody were positive for IF blocking antibody, and this agreed with the earlier work (3-5). In previous papers $(3,10)$, a small percentage of patients with various gastric abnormalities, adrenal insufficiency and thyroid diseases had an IF blocking antibody in their sera. In this survey, we found no positive results in 42 normal control sera and sera from patients without PA who had serum B12 levels less than $3,500 \mathrm{pg} / \mathrm{ml}$. On the basis of this observation, the Corning IF blocking antibody assay kit is useful for the diagnosis of PA. In some PA patients, subnormal hemoglobin levels had been documented as appearing 3 months to 6 years prior to PA recognition $(11,12)$. Sometimes it is possible to diagnose PA before detecting abnormally low serum B12 levels, or before obvious symptoms and signs of PA develop, if early detection of the IF blocking antibody is available. For these reasons, it is worthwhile to use an easy IF blocking antibody assay kit such as the Corning Medical and Scientific kit.

Sera with high B12 levels may cause false positive results in the IF blocking antibody assay $(6,13)$. It was obvious that the sera with $\mathrm{B} 12$ levels greater than $3,500 \mathrm{pg} / \mathrm{ml}$ showed frequently false positive results in this IF blocking antibody assay. Such a false positivity was usually caused by B12 injections, but not by oral B12 medication, in this survey. We also noticed that no false positive result was found in sera with endogenous high B12 levels greater than $3,500 \mathrm{pg} / \mathrm{ml}$, obtained from 10 patients with chronic myelogenous leukemia. On the other hand, sera with B12 levels less than $3,500 \mathrm{pg} / \mathrm{ml}$ revealed no false positive results, in Corning IF blocking antibody assay. It is recommendable to assay IF blocking antibody using 
sera, before giving B12 medications. Muckerheide et al. (14) mentioned that false positive results never recurred if the serum samples were collected $24 \mathrm{~h}$ after giving B12 medication, that an interval longer than $24 \mathrm{~h}$ between serum sample collection and stopping B12 medication was not necessary for avoiding false positive results in normal or PA patients. However, we experienced 3 patients who showed false positive results after stopping massive B12 medications for more than $24 \mathrm{~h}$. To avoid false positive results in this assay, it is necessary to collect serum samples with B12 levels lower than $3,500 \mathrm{pg} / \mathrm{ml}$ in patients receiving B12 medications.

In conclusion, the Corning IF blocking antibody assay kit is easy to use and has a good reproducibility. The results agree well with those obtained by the charcoal method for IF blocking antibody in PA patients. False positive results can be avoided by excluding samples with $B 12$ levels greater than $3,500 \mathrm{pg} / \mathrm{ml}$ from patients who have recently received B12 medications. We have confirmed that the incidence of IF blocking antibody was specifically high in PA patients, and the IF blocking antibody assay can be a useful aid for the diagnosis of PA. The Corning assay kit for the IF blocking antibody is available for screening in clinical laboratories.

The authors would like to express thanks to Corning Medical and Scientific (Medfield, U.S.A.) for providing the IMMO Phase IF blocking antibody assay kit.

This study was presented at the 26th General Meeting, Society of Clinical Hematology, Nagoya, October 26, 1984.

\section{REFERENCES}

1) Schwartz, M. (1958): Intrinsic factor inhibiting substance in serum orally treated patients with pernicious anaemia. Lancet, 2, 61-62.

2) Taylor, K. B., Roitt, I. M., Doniach, D., Couchman, K. G., and Shapland, C. (1962): Autoimmune phenomena in pernicious anemia: gastric antibodies. Br. Med. J., 2, $1347-1352$.

3) Irvine, W. J. (1965): Immunologic aspects of pernicious anemia. New Engl. J. Med., 273, 432-438.

4) Hansen, H. J., Miller, O. N., and Tan, C. H. (1966): Assay of autohumoral antibody that neutralizes the vitamin B12 combining site of intrinsic factor in serum from patients with pernicious anemia. Am. J. Clin. Nutr., 19, 10-16.

5) Gullberg, R. (1971): Sensitive test for antibody type I to intrinsic factor. Clin. Exp. Immunol., 9, 833-838.

6) Gottlieb, C., Lau, K-S., Wasserman, L. R., and Herbert, V. (1965): Rapid charcoal assay for intrinsic factor (IF), gastric juice unsaturated B12 binding capacity, antibody to IF, and serum unsaturated B12 binding capacity. Blood, 25, 875-884.

7) Morishita, R. (1981): Pernicious anemia. Taisha (in Japanese), 18, 59-67.

8) Jacob, E., and Schilling, R. F. (1966): An in vitro test for the detection of serum antibody to intrinsic factor-vitamin B12 complex. J. Lab. Clin. Med., 67, 510-515.

9) Kariyone, S., Morishita, R., Sato, M., Fujimori, K., Miki, M., and Nakajima, K. (1975): Radioassay of serum vitamin B12. Saishinigaku (in Japanese), 30, 621-626.

10) Rose, M. S., Doniach, D., and Ardeman, S. (1970): Intrinsic-factor antibodies in 
absence of pernicious anaemia, 3-7-year follow-up. Lancet, 2, 9-13.

11) Hall, C. A. (1965): The nondiagnosis of pernicious anemia. Ann. Intern. Med., 63, 951-954.

12) Carmel, R. (1979): Macrocytosis, mild anemia and delay in the diagnosis of pernicious anemia. Arch. Intern. Med., 139, 47-50.

13) Rothenberg, S. P., Kantha, K. R. K., and Ficarra, A. (1971): Autoantibodies to intrinsic factor: their determination and clinical usefulness. J. Lab. Clin. Med., 77, 476-484.

14) Muckerheide, M. M., Wolfman, J. A., Rohde, D. A., and McManamy, G. E. (1984): Studies on a radioassay for intrinsic factor antibody: Comparison of methods and false positive results due to elevated serum B12 level. Am. J. Clin. Pathol., 82, 300-304. 